InVisible Culture • Issue 31: Black Studies Now and the CounterCurrents of Hazel Carby

\title{
Extirpation is Not an \\ Option: An Esperantic \\ Vision of a Future for Black \\ Studies from the Other \\ Side of the Pacific
}

Will Bridges ${ }^{1}$

${ }^{1}$ University of Rochester

Published on: Nov 15, 2020

DOI: $10.47761 / 494 a 02 f 6 . f a 344734$

License: Creative Commons Attribution 4.0 International License (CC-BY 4.0). 


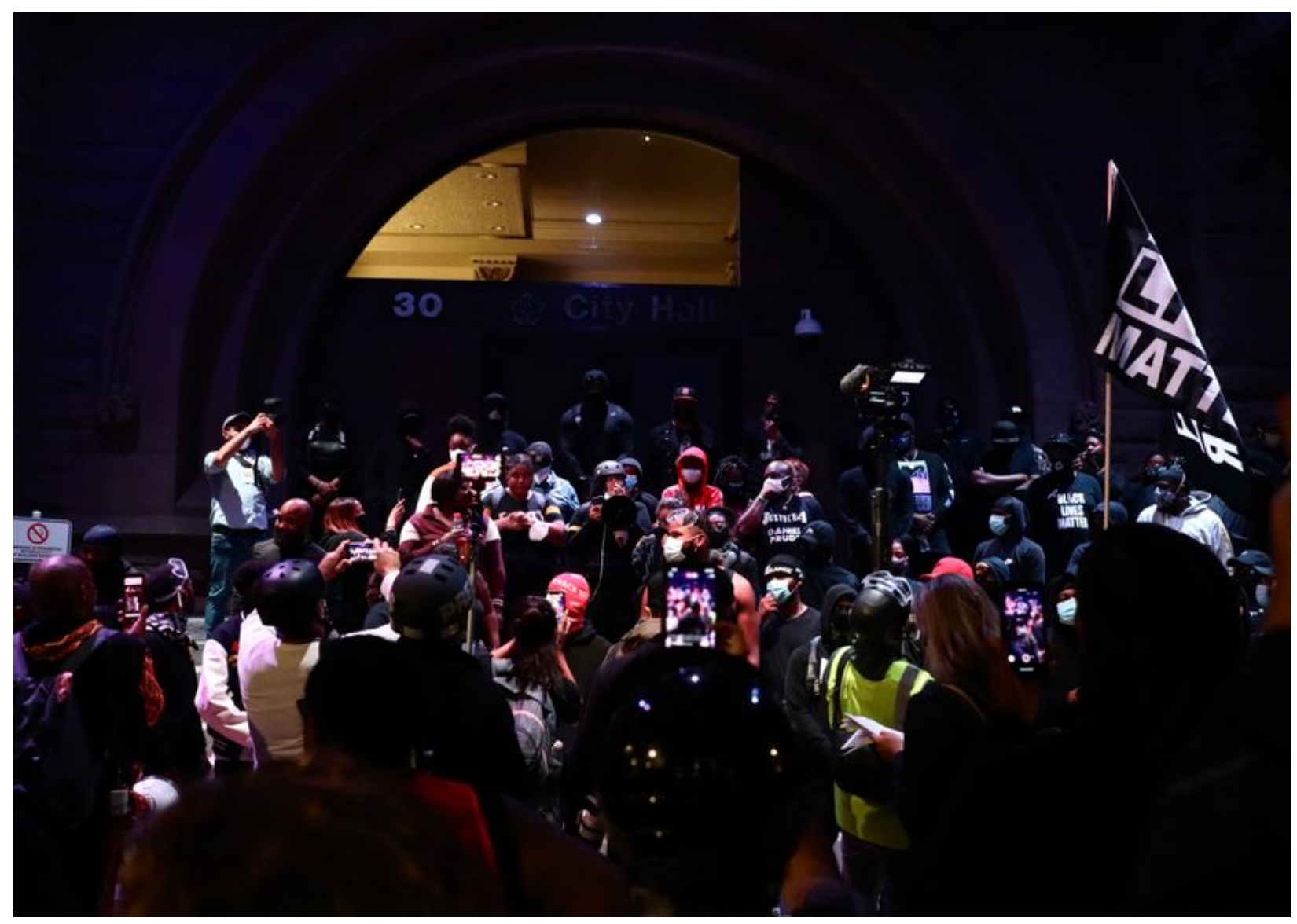

Featured Image: Protestors on the steps of Rochester City Hall, September 7, 2020. Photo by Quajay Donnell.

The promise is of "world-wide welcome" for the homeless and those yearning to breathe free. But Trump has no words of welcome for black folks from shithole countries, and he wonders why we can't court more émigrés from countries like Norway. And, as if to prove he's lost both rhyme and reason, he removes us from the Paris Agreement, even as the Institute for Environmental and Human Security of the United Nations warns that the world might see some one billion environmental migrants by 2050, with the peoples of Africa deemed "particularly susceptible" to climate displacement. $\underline{1}$

But Elon Musk thinks we'll be on Mars by then-by 2024, to be exact. For it is imperative that we, in this Musky vision of the future, become a "multiplanetary" species. But who, exactly, is the "we" here, and would this "we" be naïve to assume that "multiethnic" lies somewhere dormant and tacit but vowed within the 
multiplanetary? Musk promises to bend the cost curve of a trip to Mars to $\$ 200,000$ per passenger (the bleakest estimates of the median wealth of black families in in the ballpark of $\$ 5,000$, so each family already has $2.45 \%$ of what they need to shatter their family across the cosmos). And, if you don't have it yet, don't worry, because Japanese billionaire Maezawa Yusaku will sponsor six to eight artists from around the world to join him on a Space X mission to the moon. Didn't Maezawa pay 110 million for a Basquiat a few years back, and wasn't Musk willing to arbitrate all those racial discrimination lawsuits at Tesla? I'm sure those two will save one of those eight seats to multiplanetary salvation for someone who looks like Basquiat, right? But will eight seats be enough for Basquiat's friends and family, and their friends and family, and their friends and family? Musk will figure that one out too, I'm sure.

The water is bound to be fine on the moon; no need to worry about Martian contamination. Ten years before Musk sends us to the moon, they let those babies in Flint drink that water so they could save a couple pennies on the dollar. And this even after they knew-they knew-that their "attempts to fix" the situation "led to...levels of...chemicals that can cause long-term damage if not remedied (though we believe they will remedy them before any damage would occur in the population.)" 2 (Why are our bureaucrats slithering around in parenthetical whispers in their e-mail correspondences about a water crisis? Good question. And which "population" does Valerie Brader, then Governor Snyder's deputy legal counsel, have in mind for possible long-term damage? That's a good question too.) But maybe the Flint example is too, how should I put this... colorful. No. Terrestrial. Yes. Maybe the Flint example is too terrestrial: if you pay $\$ 200,000$ for a trip to Mars, surely the water will be fine, right?

Hell, maybe we'll even get multiethnic democracy right on the moon or Mars or somewhere else in the cosmos-maybe we just need a little more time and space to figure it out. Nothing like North Carolina and its "almost surgical precision." $\underline{3}$ Now, the hermeneutic law of shalls is notoriously difficult. But the Fifteenth Amendment is, nevertheless, palpably clear in its positing of the eradication of Herrenvolk politics as a condition of the continuing survival of democracy: the rights of citizens of the United States shall not be denied or abridged by the United States or by any State (by "State" here, we're talking our states, trying to avoid historical weight and reverberations of that states' rights business; surely we can't imagine a constitution in which voting rights are universally ensured. The task is too great for the imagination, so better not to think of it at all) on account of race, color, or previous condition of servitude. Once we get to Mars, the question will simply be if citizenship can travel light years. But light years illuminate a whole new world of meaning for that phrase "universal 
suffrage," so maybe those great tasks of imagination are exactly what we'll need going forward. But surely our multiplatenary brothers and sisters-stubs for $\$ 200,000$ tickets long since forgotten in some pocket crevice-can rest assured that the scalpel of surgical precision would never come for their voting rights, that North Carolina holds no presentiment of New North Carolina on Neptune or wherever.

I could go on. Our time together, however, is short. So let me be less prolix and as candid as I can be: Trump and his favored Norwegians, Musk and his chosen billionaires, Snyder and GM (Flint's water was corrosive to GM's bottom line, so GM's request to switch back to Detroit Water was approved by the City of Flint), more than half of the legislators in North Carolina and the parts of North Carolina they "represent"-these are all examples of those who seem to think that extirpation is an option. $\underline{4}$ The only option, in fact. For one to live, the other must die. Sometimes the deaths are organic, and sometimes the existences under assault are immaterial: for the few to be free, the many must be unfree, their freedom must die. Either way, the logic is the same-extirpative.

"Extirpation," noun, a term our colleagues in the Biology Department use as a kind of point of clarification and respect for the fact that a single species can contain multitudes of populations, that these populations of self-same species can face drastically different local conditions (different predators, different resources, different environmental stressors, and so on), and that the upshot of all of this is that a population might disappear while the species carries on. In short, the term helps us differentiate a local extirpation from the global extinction event, or, for that matter, a local extirpation from pyrrhic global survival. As we set our terms on the table, it might help us to remember that extirpation can also be deracination, total destruction, extermination, and, for only the most precise of surgeons, "the operation of removing, by excision or the application of caustics, anything having an inward growth." $\underline{5}$ Or maybe we don't need the Oxford English Dictionary at all: you know extirpative logic when you hear it. Whenever you hear a politician say that he (and it's always a he doing the saying) respects women because his mother is a woman and his daughters are too, as if the reach of the empathetic imagination can go only as far as alleles allow, the logic of extirpation is doing its tacit work, deracinating here, making excisions there.

We need a definition of extirpation in order to answer Hazel Carby's call. Any time is the perfect time to think with Carby, but Carby joined us here at the University of Rochester in January of 2019, a moment when Rochester was reimagining and 
reconstituting its vision of black studies. Carby thought with us about black studies today, about what it means to study race and racial formations at this point in political and intellectual history. And Carby called on us to consider not black studies today, but black studies tomorrow: she asked us to think not on what we wanted from the last fifty years of black studies, but what we want-and, I imagine, will want-from the next fifty years of black studies. What do we want and will we want our grand-students to write in their histories of black studies penned in the year 2070 ?

I want to answer Carby's call twice. And here, in a word, is the first answer: extirpation is not an option. We will live and die together, irrevocable reciprocity, red threads of fate entangled for all eternity.

You see, the Trumps and the Musks and the Snyders and the halves of the North Carolina legislatures (and, in our darker and more honest moments, the yous and the mes) of the world seem to think that extirpation is an option. How else to explain our collective responses - a fret and a sigh, but then a hop, skip, and a jump right back to our business-as-usual ways of seeing and being in the world-to Flint or to North Carolina or to the reports of the United Nations Intergovernmental Panel on Climate Change? The report says right there, clear as day, that the evidence of the "warming of the climate system is unequivocal," that "recent anthropogenic emissions of greenhouse gases are the highest in history," that "warming is more likely than not to exceed 4 degrees C above pre-industrial levels by 2100," and that the "risks associated with temperatures at or above 4 degrees $C$ include substantial species extinction, global and regional food insecurity, [and] consequential constraints on common human activities...(high confidence).”ㅌ

...But...the report also says that the "risks are unevenly distributed and are generally greater for disadvantaged people and communities in countries at all levels of development," that it's just "a large fraction" of species that will bear the weight of "increased extinction risk due to climate change during and beyond the 21st century, especially as climate change interacts with other stressors (high confidence)." $\underline{7}$ So the logic, fundamentally extirpative in its twists and turns, with which the Trumps and Musks of the world respond to a report such as this (when they respond at all) goes something along the lines of: Fuck the UN. I am fundamentally uninterested in their "high confidence" sketches of possible futures. Because their vatic visions paint pictures of futures that do not belong to me or anyone who looks like me or anyone about whom I care. The masses can huddle and yearn to breathe free all they want. 
Now, if they would like to purchase some silverware for the cake I'll let them eat, they know where to find me. But, barring that...

So, if we want the black studies scholars of 2070 or 2100 or whenever to have the resources (with life, of course, being the most precious of resources) with which to write what will be our histories of the future, we will need someone to convince everyone that extirpation is not an option, that the only good is common, that the survival of the few cannot be paid for with the flesh of the many, that our ability to cooperate (to co-operate, to be and act together) and co-exist (not just tolerating the fact that some other existence might sit beside me on the bus, but to see the boundaries of our existences as encompassing every other existence, and, more importantly, to see that this whole existence thing is bigger than you or me, which means that we should hope for the continuing co-existence of all the other existences whether I carry on existing or not) will determine whether we all live or die together.

Someone has to convince everyone. (NB: in conjecturing a need to convince, I am, of course, assuming that education is preferable to mobilization, that democratic, forceful argumentation is preferable to force, full stop.) It seems to me that black studies might be the best studies for articulating the inconceivability of extirpation, that we might be the best someone to convince everyone. If pressed to distill the center of gravity of black studies into a single sentence-if, in other words, we tried our hand at the inevitably reductive thought experiment of proposing a thesis statement for black studies, we could do much worse than to posit "extirpation is not an option" as the field's organizing logos, ethos, and, pathos.

Before we had black studies proper, we had W.E.B. Du Bois, who was writing at a moment when the very concept of "human sciences" was codifying and congealing. Du Bois proffered "The Study of the Negro Problems" as investigations of "microcosmic reproductions of long centuries of world history, and rapid-even violent-repetitions of great social problems"; to refuse black studies, Du Bois thought, would be to "hurt the cause of scientific truth the world over, [to] voluntarily decrease human knowledge of a universe of which we are ignorant enough, [to] degrade the high end of truthseeking in a day when they need more and more to dwell upon its sanctity." $\underline{8}$ The "study of the Negro problem" was, for Du Bois, not a matter of extirpation, but a microcosmic glimpse into a world, a universe to come for us all.

When we got black studies "proper"-we got it, as Noliwe Rooks reminds us, on the heels of a world war and in the midst of a cold one-extirpation seems much less likely against the backdrop of Vietnam, conscription, and mutually assured destruction. So 
even though, Rooks reports, "the familiar narrative chronicling the beginning of Black Studies generally centers on Black student protest and violence, in reality, at San Francisco State, Black, white, Native American, Asian, and Latino students rose up together, joined forces, and made or supported unequivocal demands" of, to borrow a piece of the name of one of the student organizations protesting at San Francisco State in 68 , world liberation. $\underline{9}$

And, now that we have black studies "proper," our syllabi are filled with folks insisting that extirpation is not an option. Examples abound. King: "Injustice anywhere is a threat to justice everywhere. We are caught in an inescapable network of mutuality, tied in a single garment of destiny. Whatever affects one directly, affects all indirectly.”10 Baldwin: “...Italians, Greeks, Spaniards, Irishmen, Poles, Persians, Norwegians, Swedes, Danes, wandering Jews from every nation under heaven, Turks, Armenians, Lithuanians, Japanese, Chinese, and Indians. Everybody was here suddenly in the melting pot, as we like to say, but without any intention of being melted... Whether I like it or not, or whether you like it or not, we are bound together forever. We are part of each other. What is happening to every Negro in the country at any time is also happening to you. There is no way around this." 11 Ellison: "Our fate is to become one, and yet many-This is not prophecy, but description." 12 Butler: "I can't do a thing about my hyperempathy, no matter what Dad thinks or wants or wishes. I feel what I see others feeling or what I believe they feel...I'm supposed to share pleasure and pain, but there isn't much pleasure around these days...Anyway, my neurotransmitters are scrambled and they're going to stay scrambled." 13 Carby:

Both of my parents grew up poor on islands more than 4,000 nautical miles apart from each other...But they were not stranger to each other when the met. The distance between Britain and Jamaica cannot take the measure of their Britishness, realized as a structure of ethics and values made coherent through shared ideas about empire. Iris and Carl were conscripted before either could fully comprehend how the circumstances of their becoming might have been otherwise...When war drew them into its orbit they eagerly embraced the upheavals in their lives, dusted off the dreams and ambitions they had previously considered unattainable, and ran toward the possibility of infinitely expanded futures. $\frac{14}{4}$

Fiasco: "Let's go to sleep in Paris/Wake up in Tokyo/Have a dream in New Orleans/Fall in love in Chicago, man/Then we can land in the motherland/Camel-back across the 
desert sand/and take a train, to Rome, or home/Brazil, for real/Wherever I go she goes/Wherever I go she goes/Wherever I go she goes/Wherever I go she goes." 15 Riri: "Because/When the sun shines, we shine together/Told you I'll be here forever/...Now that it's raining more than ever/Know that we still have each other/You can stand under my umbrella/You can stand under my umbrella, ella, ella, eh, eh, eh.”트 And so on.

The impossibility of extirpation inherent to the very project of black studies makes itself particularly legible in my corner of the field. My work is concerned with the possibilities of the black Pacific in general and those of what we might call Afro-Japan in particular. Nahum Chandler reminds us that "matters of 'blackness' (or color in some general metaphoric sense as Du Bois proposed it) and matters 'Japanese' have long been implicated in one another," and that this implication gestures toward the possibilities of a new sense, new senses, and new sensations of what might come to be, that, in other words, the "affirmation of a future 'colored' Japan," as Chandler continues, has "far reaching capacities to contribute to a sustainable, generative, and re-generative future for human groups in world-wide relation across the planet." 17

For our purposes, I want to suggest that one of the new sensations made visible by the study of things Afro-Japanese in Japan was a palpable sense that extirpation is not an option. For this sense is at the very heart of the origins of black studies in Japan. The first meeting of the Kokujin kenkyū no kai (The Japanese Association for Negro Studies, now the Japanese Black Studies Association) was held on June 22, 1954—not even a decade removed from Hiroshima and Nagasaki and the Tokyo Trials, only two years removed from the conclusion of Allied Occupation of mainland Japan, and when the members of the Association would have still had memories of the Occupation-era food crisis in their bellies. One would think that Japan still had much work to do to ensure its own survival and get its own political house in order, that Japan, in other words, would be worried about local extirpation rather than global reverberation. So why, then, did the original eight members of the Japanese Association for Negro Studies gather at their headquarters at the Kobe City University of Foreign Studies on June 22, 1954 and turn their attention not just toward black folks in America, but in the Americas, Africa, Asia, Europe and any place black life might be found?

There are, of course, many answers to this question. But one of its answers rests in the sense of Nukina Yoshitaka (1911-1985), professor of American literature and culture and the founder of Japan's Association for Negro Studies, that an attempt to ensure 
the continuing existence of a democratic Japan (read: a Japan's whose future would not look like its fascist past) required the nation to turn its attention toward black studies.

The Allied occupation of postwar Japan came, ostensibly, as a force for liberation. And American liberation brought with it democratic promises of life, liberty, and happier pursuits for not just the Japanese, but for any people the world over who were willing to adhere to the tenets of American-style liberal democracy. Indeed, this promise was written into the very opening words of the constitution the Allies drafted for the postwar Japanese: "We, the Japanese people...determine that we shall secure for ourselves and our posterity...the blessings of liberty throughout this land...We desire to occupy an honored place in an international society striving for the preservation of peace, and the banishment of tyranny and slavery, oppression and intolerance for all time from the earth. We recognize that all peoples of the world have the right to live in peace, free from fear and want."토

Two years into the occupation of Japan, however, democratic promises of peace, liberty, and freedom began to fade. With the red threat rising abroad and the Japanese Communist Party ascendant at home-legalized by the Allied powers in a show of postwar Japan's newfound political freedom in 1945, the Japanese Communist Party made the mistake of taking the Americans at their word and exercising said political freedom, winning some $10 \%$ of the national vote in 1949-the Allied Occupation initiated what is known as the Reverse Course, a series of policies that privileged containment of the communist threat (red purges, union busting, and the like) over the liberal political reformation of Japan.

I do not think it is too hyperbolic to suggest that the "reversal" of America's commitment to the project of liberating and liberalizing Japan struck Nukina as a matter of worldwide life and death. Nukina had seen the atrocities of occupied Java as a conscript of the Imperial Japanese Army, and he had read the 1944 Japanese translation of Du Bois's The Negro, in which Du Bois reminds us that:

[T]here were half a million slaves in the confines of the United States when the Declaration of Independence declared 'that all men are created equal; that they are endowed by their Creator with certain unalienable rights; that among these are life, liberty, and the pursuit of happiness...In order for this colored world to come into its heritage, must the earth again be drenched in the blood of fighting, snarling human beasts, or will Reason and Good Will prevail? $\underline{19}$ 
In other words, Nukina had seen with his own eyes what it would mean for Japan to "reverse course" toward its wartime past; Nukina also had visions-from his reading of Du Bois, but also from the research he conducted for his two-part article series on American slavery and abolitionists published in 1949 and 1951-of the catastrophic ramifications for people both at home and abroad when America fails to live up to the promises written in its founding documents.

One of the "reasons," then, that Nukina turns to the creation of an association for black studies in the ruins of postwar Japan is that he understood, with Du Bois, that black studies provides us with the most precious of gifts: the possibility of epistemological transformation, one which can help us see the world, its history, and its future anew. The transformed sense of things offered by black studies helps us see through the various reversals of political vicissitudes and think through whether America is keeping the promises of its founding political philosophy. In Yuichiro Onishi's words, the Association for Negro Studies was interested in the cultivation of a kind of "cognitive clarity," one which would enable an ability "to think through race to unmask the face of American liberal democracy and render visible a new intellectual tradition." $\underline{20}$ And, in the face of the most powerful empire the world has ever known, the ability to think through whether America is keeping its philosophical-political promises is a matter of everybody's survival.

Or, to revisit my summation, Nukina turned to black studies because extirpation is not an option: in the example noted here, the survival of Japanese democracy-and, more importantly, of the people who depend on democracy in order to ensure their survivaldepends on the survival of American democracy, which depends on what Eddie Glaude once called democracy in black, which, in turn, would have reverberance for democracies the Cold War world over. In his history of the formation of the Japanese Association for Negro Studies, Furukawa Hiromi (a former student of Nukina, founding member of the Association, and prolific scholar of Afro-Japanese history in his own right) noted that the Association took up "black studies in an age when the field had yet to be inaugurated in the United States" because the field offered "a kind of metric for the attainability of American democracy." $\underline{21}$ And this metric, in turn, provides an invaluable measurement not just for postwar Japan, but for the world. This is why, as Furukawa notes elsewhere, the Association's charter did not include "any limitation on the geographical reach of its object of study," which both "positioned the association to respond flexibly" to question of blackness the world over and to grow the Association's circle of members limitlessly. $\frac{22}{2}$ 
And the openness of the Association's intellectual boundaries reminds me of the easiest way to evince the fact that Nukina did not deem extirpation an option. The Association's structure was highly informed by Nukina's near lifelong dedication to Esperanto. Nukina began teaching himself Esperanto at age 12. Five years later, he joined the Osaka Esperanto Study Group, and he would join Japan's national Esperanto society, Nihon Esperanto Gakkai, in 1935. The war took Nukina away from his studies, but he returned to them upon repatriation. Since even before the war, Esperanto in Japan had long held a kind of gravitational pull for Japan's intellectual left and its vision of a lingua franca of worldwide peace and solidarity, but, in the war's aftermath, and with the Allied opening of political discourse, the Japanese Communist Party (JCP) took an acute interest in Esperanto. The postwar Esperantists attracted by this gravitational pull formed the Japan Esperanto Association, which was affiliated with the Party by way of the Japan Democratic Culture League, an umbrella organization for the JCP's network of popular front cultural activities and associations. (More agnostic Esperantists formed the politically-neutral Japanese Esperanto Society).

In the immediate postwar years, Nukina was the head of his prefectural branch of the Japan Esperanto Association in Hyogo. And, when a red purge culminated in the dissolution of the Japan Esperanto Association in 1950, Nukina was a founding force and inaugural head of the Kansai Esperanto League in 1951. Nukina's stewardship of the Kansai Esperanto League, then, occurred concomitantly with his work to establish the Association for Negro Studies. The very formation of the Association for Negro Studies in Japan is shot through with Esperantist sensibility. Nukina consulted and recruited in Esperantist circles during the Association's conception. Moreover, one of the co-founding members of the Association, the aforementioned Furukawa Hiromi, was a fellow Esperantist whom Nukina reunited with serendipitously at an Esperantist meeting. The Association's organization as an "association" (kai in Japanese) open to anyone interested in black studies rather than as a purely scholastic society, its lack of an official director during its inaugural years, its focus on collaborative translations of works of black literature into Japanese-in both logistics and logics, the Association for Negro Studies was informed by a JCP-style vision of Esperanto.

The importance of this piece of history is right there in the language's name: the Esperantist is one who hopes. The creation of an association for black studies in Japan, then, was irrevocably intertwined with the positing of an affective reorientation toward futurity in the postwar period. It was intertwined with a desire for a universal language of hope, an open-door, transnational community of those longing for peace and an articulable recognition of our shared humanity. This is precisely the hope 
harbored by Ludwik Zamenhof, the initiator of Esperanto. The objective of Esperanto was, in Zamenhof's vision, never to achieve the perfect language. Rather, the objective was to create a community of radical cosmopolitanism around the shared project of the democratic creation of a universal language. Esperanto was "only a fraction of a larger project," a project toward, in Zamenhof's words "the unification of humanity in one fraternal family." 23 This project is what Zamenhof called in his opening address to the Second Esperanto Congress the "inner idea" of Esperanto. Those hoping for this inner idea "will not be afraid when the world jeers at them and calls them utopian, and when the chauvinists attack their ideals as criminal. They will be proud to be called utopians. At every new congress, their love for the internal idea of Esperantism will be stronger, and little by little our annual congress will be a constant celebration of humanity and of human brotherhood." $\underline{24}$

For even someone with an understanding of Esperanto as rudimentary as mine, it is clear that the lexicology of the language itself is imbued with this inner idea. One has a mother tongue, an organic language claimed as possession and personal property. One participates in Esperanto, a cyborganic, modular language shared with the community. This participation entails learning roots, but also realizing that these roots are almost infinitely recombinable. After this realization, one attaches grammatical endings, prefixes, and suffixes to these roots pragmatically, creating a potentially endless flow of neologisms - those new words by which we will communicate in and with the future -in order to meet the ever-evolving communicative needs of the language community as they expand eternally into unknown futures. This design is proffered in hope of a universal language with the flexibility to include any new member, foreseen or unforeseen, whom the community might encounter.

If I see the "inner idea" of Esperanto at the rudimentary level, I can only assume that Nukina envisioned it with his mastery, and that his vision is in part why he modeled the Association for Negro Studies on Esperanto circles. We might call this Nukina's Esperantic vision for black studies.

(Although it goes without saying, perhaps it goes better with saying that, if it is possible to posit an Esperantic view of black studies, it is also possible to postulate something like a black studies vision of Esperanto. This vision might propose a proviso along the following lines. Hope somehow manages to simultaneously be one of the most courageous and one of the most naïve affective stances we can take in relation to the future. For hope mitigates the weight of archival evidence of the atrocities of yesterday as it posits the possibility of a better tomorrow. But "mitigation" is not the 
same as "evaporation" - the privileges of the mother tongue do not disappear with the adoption of a universal language. Pano, butero kaj verda fromaĝo, so our adaptation of the rhyme goes, estas bona Spanglisho kaj bona Esperanto. In short, history will have its say in even the most hopeful of futures.)

With Nukina's Esperantic vision of black studies in mind, the date of the Association's first meeting, June 22, 1954, was significant not because of its proximity to any particular date on Japan's calendar in the past. Rather, it was significant insofar as it marked an attempt to inaugurate a field of study that ties all the dates of world history to the entirety of world futures. Nor was it was lost on Nukina and his colleagues that June 22, 1954 followed May 17, 1954, the day of the decision of Brown v. Board of Education. The question at the heart of their endeavor was this: going forward, how integrated should our educations and curricula be? Following Nukina, it seems to me that, if extirpation is not an option, then everyone's education must be woven with everyone else's, and that black studies is the best studies for configuring and articulating the interdependence of our educations.

I mentioned earlier that I want to answer Hazel Carby's question-what do we want and will we want from the next fifty years of black studies?-twice. Here is the second answer. The answer begins with the simple fact that I want black studies, and all the folks who might study it, (and all the folks who might not study it), to be. If we want black studies and all these potential students and non-students to still be in the future, we will have to ensure that the planet, institutions, and philosophies upon which black studies depends for its ongoing existence are not eradicated. The job of procuring this insurance is too big for any one person, or, rather, it is too big to be done without any one person, for the survival of the planet and institutions like democracy and philosophies like isonomia require, by definition, that either we all get it or no one does.

We might say, then, that the task of black studies for the next fifty years is the same as its task from the last fifty years: to save the world from itself. It is not the task that has changed, but the world black studies finds itself in. For now we are in a world that runs the risk of imploding multiple realities, a world which will continue to be for some -scarred, yes, altered, irrevocably, but continuing to exist nevertheless for the chosen few-and fade from existence for others. Our task going forward will be to put the world back together, to explain how we live and die as one, to educate options beyond extirpation into existence. 


\section{Footnotes}

1. Kamal Baher, "Climate Migrants Might Reach One Billion by 2050," Inter Press Service, August 21, 2017, http://www.ipsnews.net/2017/08/climate-migrants-mightreach-one-billion-by-2050.

2. Julie Mack, "Emails Show Flint Water Crises Through Eyes of Gov. Snyder's Top Aides," Michigan Live, May 6, 2016, last modified May 23, 2019, https://www.mlive.com/news/2016/05/flint water_crisis emails.html. $\leftrightarrows$ 3. Adam Liptak and Michael Wines, "Strict North Carolina Voter Id Law Thwarted after Supreme Court Rejects Case," The New York Times, May 15, 2017, A1. 4. For more on GM and Flint water, see Laura Pulido, "Flint, Environmental Racism, and Racial Capitalism," Capitalism Nature Socialism 27, no. 3 (2016): 1-16. 5. “Extirpation, n.," definition 2b, OED Online (Oxford University Press), accessed October 20, 2020, https://www.oed.com/view/Entry/67038.

6. Intergovernmental Panel on Climate Change, “Climate Change 2014: Synthesis Report. Contribution of Working Groups I, II and III to the Fifth Assessment Report of the Intergovernmental Panel on Climate Change," 2,

18, https://www.ipcc.ch/site/assets/uploads/2018/02/SYR_AR5_FINAL_full.pdf, emphasis in original. $\subseteq$

7. IPCC, “Climate Change 2014,” 13.

8. W.E.B. Du Bois, The Problem of the Color Line at the Turn of the Twentieth Century: The Essential Early Essays, ed. Nahum Dimitri Chandler (New York:

Fordham University Press, 2014), 77, 78, 85.

9. Noliwe Rooks, White Money/Black Power: The Surprising History of African American Studies and the Crisis of Race and Higher Education (Boston: Beacon Press, 2006), 5. $匚$

10. Cited in Jonathan Rieder, Gospel of Freedom: Martin Luther King, Jr's Letter from Birmingham Jail and the Struggle that Changed a Nation Gospel of Freedom (New York: Bloomsbury Publishing, 2014), 170. 11. James Baldwin, "In Search of a Majority," in The Price of the Ticket: Collected Nonfiction 1458-1985 (New York: St. Martin’s, 1985), 231, 234. 
12. Ralph Ellison, Invisible Man (New York: Vintage), 576-577.

13. Octavia Butler, Parable of the Sower (New York: Grand Central Publishing, 2000), 12, emphasis in original. $\leftrightarrows$

14. Hazel Carby, Imperial Intimacies: A Tale of Two Islands (London; New York: Verso, 2019), 19-20. $匚$

15. Lupe Fiasco, "Paris, Tokyo," Lupe Fiasco's The Cool, 2007, Atlantic, CD. 16. Rihanna, “Umbrella,” Good Girl Gone Bad, 2007, SRP, CD. $ヒ$

17. Nahum Chandler, "Introduction: On the Virtues of Seeing-At Least, but Never Only-Double," CR: The New Centennial Review 12, no. 1 (2012): 4-5.

18. "The Constitution of Japan," last accessed November 24, 2019, https://jâpan.kantei.go.jp/constitution_and_government_of jạpan/constitution e. html. $\doteq$

19. W.E.B. Du Bois, The Negro (New York: Cosimo Classics, 2007), 110, 146. 20. Yuichiro Onishi, Transpacific Antiracism: Afro-Asian Solidarity in 20th-Century Black America, Japan, and Okinawa (New York: NYU Press, 2013), 116.

21. Hiromi Furukawa and Tetsushi Furukawa, Nihonjin to Afurika-kei Amerikajin : Nichi-Bei kankeishi ni okeru sono shosō (Tokyo: Akashi Shoten, 2004), 13.

22. Hiromi Furukawa, "Sōsetsu 40 shūnen ni mukete: Kaiko to kadai," Kokujin kenkyū 63 (1993): 2.

23. Roberto Garvia, Esperanto and Its Rivals: The Struggle for an International Language (Philadelphia: University of Pennsylvania Press, 2015), 88-89.

24. Garvia, Esperanto and Its Rivals, 90. 